\title{
Identification and characterization of phytoconstituents of ethanolic root extract of Clitoria ternatea L. utilizing HR-LCMS analysis
}

\author{
Jiji K N \& Muralidharan $\mathrm{P}^{*}$ \\ Department of Pharmacology, C.L.Baid Metha College of Pharmacy, (Affiliated to Tamil-Nadu Dr.M.G.R Medical University), Chennai 600 097, \\ India \\ *Email: clbmpharmacology@hotmail.com
}

\section{ARTICLE HISTORY}

Received: 22 February 2021

Accepted: 21 May 2021

Available online: 01 July 2021

\section{KEYWORDS}

Central nervous system

Ayurvedic formulation

Phytochemical evaluation

Medicinal plants

\begin{abstract}
Medicinal plants act as a vital source in improving health and overcoming the side effects of modernday medicine. Many evidence-based reports are present in the literature about the benefits of medicinal plants. Clitoria ternatea L. belongs to the family Fabaceae and is known to be one of the important Ayurvedic medicinal plant whose uses are specified mainly for the modification of nervous system activities. 'Medhyarasayana' is one of the Ayurvedic formulations which is used to promote the intellectual capacity, revive the body and nervous tissue, Clitoria ternatea serves as a major constituent of 'Medhyarasayana.' Identification and characterization of active metabolites of $C$. ternatea will help to isolate the important phytoconstituents responsible for the central nervous system effects, isolated components can be utilized in future for the formulation of new medicine for various neurodegenerative disorders. In the present study, the phytochemical evaluation of the ethanolic root extract of $C$. ternatea (EECT) was performed using the HR-LCMS technique. Preliminary qualitative phytoconstituents analysis showed the presence of tannins, alkaloids, saponins, steroids, carbohydrate, protein, flavonoids and triterpenoids in the ethanolic root extract. Almost 42 compounds were identified when the EECT subjected to HR-LCMS analysis.
\end{abstract}

\section{Introduction}

Medicinal plants are considered as amusing resources of ingredients that can be used in drug discovery and development as they are a very vital source to improve health and to overcome adverse effects of allopathic medicine. Many evidence-based reports are present in the literature about the benefits of medicinal plants and their biochemical and molecular effects (1). Worldwide a huge percentage of the population utilize medicinal plants and herbs for their health purpose. Therefore, scientific scrutiny of their phytoconstituents, therapeutic potential, biological properties and safety will be valuable in making wise decisions about their use. $(2,3)$ Ayurveda is one of the most popular Indian traditional health care systems which labels several herbal preparations which are well-known to uphold health and endurance. 'Rasayana' is the common term representing one of such herbal preparations which is ultimate for the progress of tissue functions in addition to their role as micronutrients (4). 'Medhyarasayana' is an Ayurvedic preparation made from the selected plant extracts to revitalize the brain by acting on the nervous system (5).
Clitoria ternatea $\mathrm{L}$. belongs to the family Fabaceae, is a perennial twining herb with terete steam. It possess two varieties- white-flower and blue flower varieties (6). The local name is 'Shankhpushpi' and this is one of the 'Medhyarasayana' ingredients and is reported to promote intellectual capability, revive the body and nervous tissue and because of all these properties it has been widely used as a brain tonic (6). Scientific studies also reported other medicinal properties including antidepressant and anticonvulsant (7), anti-inflammatory, analgesic and antipyretic (8), local anesthetic (9), purgative (10) and anti-diabetic (11) activity. It is also used for the treatment of snakebite and scorpion sting in India (12). In the present study, the phytochemical evaluation of the ethanolic root extract of $C$. ternatea (EECT) was performed using the HR-LCMS technique.

\section{Materials and Methods \\ Collection and Preparation of Clitoria ternatea root extract}

Fresh roots of the white variety of wild C. ternatea were collected from Kerala, India. Authentic 
identification was carried by taxonomist Prof.P.Jayaraman, Director, Plant Anatomy and Research Centre, West Tambaram, Chennai. India. A voucher specimen (SES.CLBM.NO. 1458) has been deposited at the Herbarium of Department of Pharmacognosy, C.L.Baid Metha College of Pharmacy, Chennai, India. The collected materials were shade dried at room temperature to remove moisture, then coarsely powdered by using an electric grinder. The powdered materials were stored in an air-tight container and used for further extraction.

\section{Extraction procedure}

Extraction of roots was carried out using ethanol by continuous hot extraction method using Soxhlet apparatus. The obtained extract was concentrated by gentle heating followed by using rotarat vacuum evaporator. The concentrated extract was then weighed, calculated the percentage yield and stored. The extract was subjected to various preliminary phytochemical tests and HR-LCMS analysis (13). The qualitative phytochemical tests were performed for alkaloids, flavonoids, glycosides, phenolics, terpenoids, saponins, carbohydrate, protein, amino acids and triterpenoids $(14,15)$.

\section{High-Resolution Liquid Chromatography and Mass Spectrometry (HR-LCMS) analysis}

The HR-LCMS analysis of the extract was carried out in Sophisticated Analytical Instrument Facility (SAIF), IIT Bombay, Mumbai. Methanol was used as the solvent for the preparation of extract and this process was done before subjecting the extract for analysis. Agilent high-resolution liquid chromatography and mass spectrometry model- G6550A $(0.01 \%$ mass resolution) was used to prepare the chemical fingerprints of the subjected extract. The acquisition method was set to be Mass- minimum range 50 dalton $(\mathrm{M} / \mathrm{Z})$ and maximum 1000 Dalton $(\mathrm{M} / \mathrm{Z})$. The scanning was done with a rate of each spectrum per second (16).

Hip sampler G4226A-model with ancillary speed $100 \mu \mathrm{l} / \mathrm{min}$, ejection speed $100 \mu \mathrm{l} / \mathrm{min}$, flush out factor $5 \mu \mathrm{l}$ and $8 \mu \mathrm{l}$ injection volume was used for HR-LCMS. (15) Acquisition time was $30 \mathrm{~min}$ with initial $2 \mathrm{~min}$ of the flow of solvent. The solvent composition used for HR-LCMS was 95: 5-100\% water and 100\% Acetonitrile. Column details -Hypersil GOLD C18 100 x 2.1mm-3MICRON.

\section{Identification of components}

Interpretation on mass spectrum HR-LCMS was carried out by comparing the spectrum of unknown components with known components spectrum. For comparison, we have utilized the SAIF -IIT Bombay database, where they have been stored more than 62000 patterns of the spectrum. The name, molecular weight and structure of the components of the trial materials were determined.

\section{Results and Discussion}

The percentage yield of (EECT) was found to be $10.4 \% \mathrm{w} / \mathrm{w}$. Preliminary phytochemical evaluation of EECT showed the presence of tannins, alkaloids, saponins, steroids, carbohydrate, protein, flavonoids and triterpenoids (Table 1).

HR-LCMS analysis of EECT showed different major peaks indicating the presence of various phytochemical constituents. The characterization and identification of constituents were done by performing a comparison with the HRLC-MS spectrum of SAIF library compounds. The HR-LCMS study was performed for both positive and negative mode of ionization, the respective chromatogram is represented in Fig. 1 and Fig. 2. The fingerprint obtained was interpreted and mentioned (Table 2, 3). Positive ionization ESI of EECT showed 24 compounds and negative ionization ESI of EECT showed 18 compounds. The MS zoom spectrum of few important compounds identified by both positive and negative ionization ESI are also represented (Fig. 3, Fig. 4).

Neuropharmacologic effects of various crude root extract of $C$. ternatea were reported by different researchers. It was reported that the oral intubation of CT aqueous root extract had shown a significant increase in learning and memory of postnatal and young adult Wistar rats (17). In another study, there are reports the in vitro effects of $200 \mathrm{mg} / \mathrm{ml}$ of $C$. ternatea aqueous root extract on proliferation, differentiation and growth of anterior subventricular zone neural stem cells derived from prenatal and postnatal rat pups (18). Acetylcholine (ACh) and Acetylcholinesterase (AChE) activity modification in connection with memory and cognitive enhancement of laboratory rodents upon administration of various root extracts of $C$. ternatea was reported by various researchers $(19,20)$. Anti-depressant and anti-anxiety effects of different root extracts have been studied and reported by different scientists $(21,22)$.

Even though the preclinical trial on rodents with various crude root extract of $C$. ternatea reported promising results on nervous system, a detailed study on isolated compounds from the root was not done so far. The present study imparts light on various constituents in root ethanolic extract. As per the results of the present study, the identified compounds like Chelidonine, Gibberellin, Elephantopin, Deoxy sapponone B 7,3'-dimethoxy ether acetate, 3 hydroxy3'4'-dimethoxy flavone, Tubernoic acid, Pectolinarin, Isotectorigenin 7-methyl ether, Mucronulatol, Biochanin A dimethyl ether and different amino acids may be responsible for the reported effects produced by the root. For the confirmation, a detailed fractionation and constituent's isolation research study have to be performed on its roots. A welldesigned constituent isolation and preclinical studies with those isolated compounds will confirm the safety and efficacy of $C$. ternatea against different neurological disorders.

\section{Conclusion}

The present study investigated and specified the various active metabolites found in the ethanolic root extract of Clitoria ternatea by carrying out different qualitative phytochemical screening and HR-LCMS analysis. The results serve as a potential resource to explore the isolation, purification and pharmacological screening of 
Table 1. Preliminary phytochemical screening of ethanolic root extract of Clitoria ternatea L.

\begin{tabular}{|c|c|c|c|}
\hline Sl.no. & Test & Extract & Inference \\
\hline \multirow{4}{*}{ I } & Test for carbohydrates & & \\
\hline & Molisch’s test & + & Presence of carbohydrates \\
\hline & Benedicts test & + & Presence of carbohydrates \\
\hline & Fehlings test & + & Presence of carbohydrates \\
\hline \multirow{3}{*}{ II } & Test for tannins and phenolics & & \\
\hline & Lead acetate test & + & Presence of phenolics and tannins \\
\hline & Ferric chloride test & + & Presence of phenolics and tannins \\
\hline \multirow[t]{3}{*}{ III } & Test for steroids & & \\
\hline & Salkowski's test & + & Presence of steroids \\
\hline & Libermann Burchard test & + & Presence of steroids \\
\hline \multirow[t]{3}{*}{ IV } & Test for triterpenoids & & \\
\hline & Isoprenoid test & + & Presence of triterpenoids \\
\hline & Test for flavones and flavonoids & & \\
\hline \multirow[t]{4}{*}{$\mathrm{V}$} & Shinoda test & + & Presence of flavanoids \\
\hline & Aqueous sodium hydroxide test & + & Presence of flavanoids \\
\hline & Test for alkaloids & & \\
\hline & Mayer's test & + & Presence of alkaloids \\
\hline \multirow[t]{3}{*}{ VI } & Hager's test & + & Presence of alkaloids \\
\hline & $\underline{\text { Dragendroff's test }}$ & + & Presence of alkaloids \\
\hline & Wagner's test & + & Presence of alkaloids \\
\hline \multirow[t]{3}{*}{ VII } & Test for Glycosides & & \\
\hline & Liebermann's test & + & Presence of glycosides \\
\hline & Borntrager's test & + & Presence of anthroquinone glycosides \\
\hline \multirow[t]{4}{*}{ VIII } & Test for Proteins & & \\
\hline & Millon's test & + & Presence of proteins \\
\hline & Biuret test & + & Presence of proteins \\
\hline & Ninhydrin test & + & Presence of proteins \\
\hline \multirow[t]{2}{*}{ IX } & Test for Saponins & & \\
\hline & Foam/Froth test & + & Presence of saponins \\
\hline
\end{tabular}

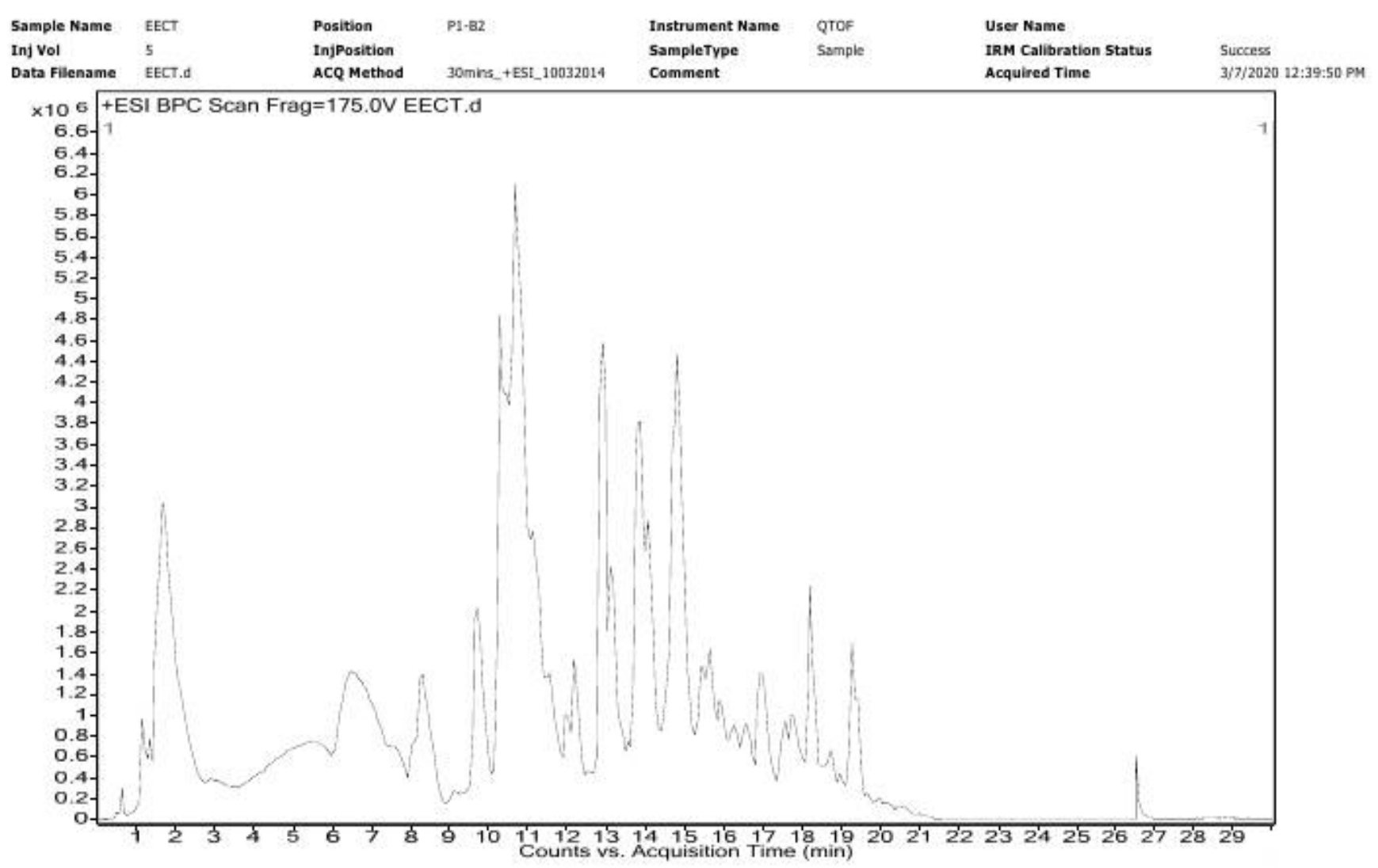

Fig. 1. HR-LCMS chromatogram (Positive ESI) of ethanolic root extract of Clitoria ternatea L. 


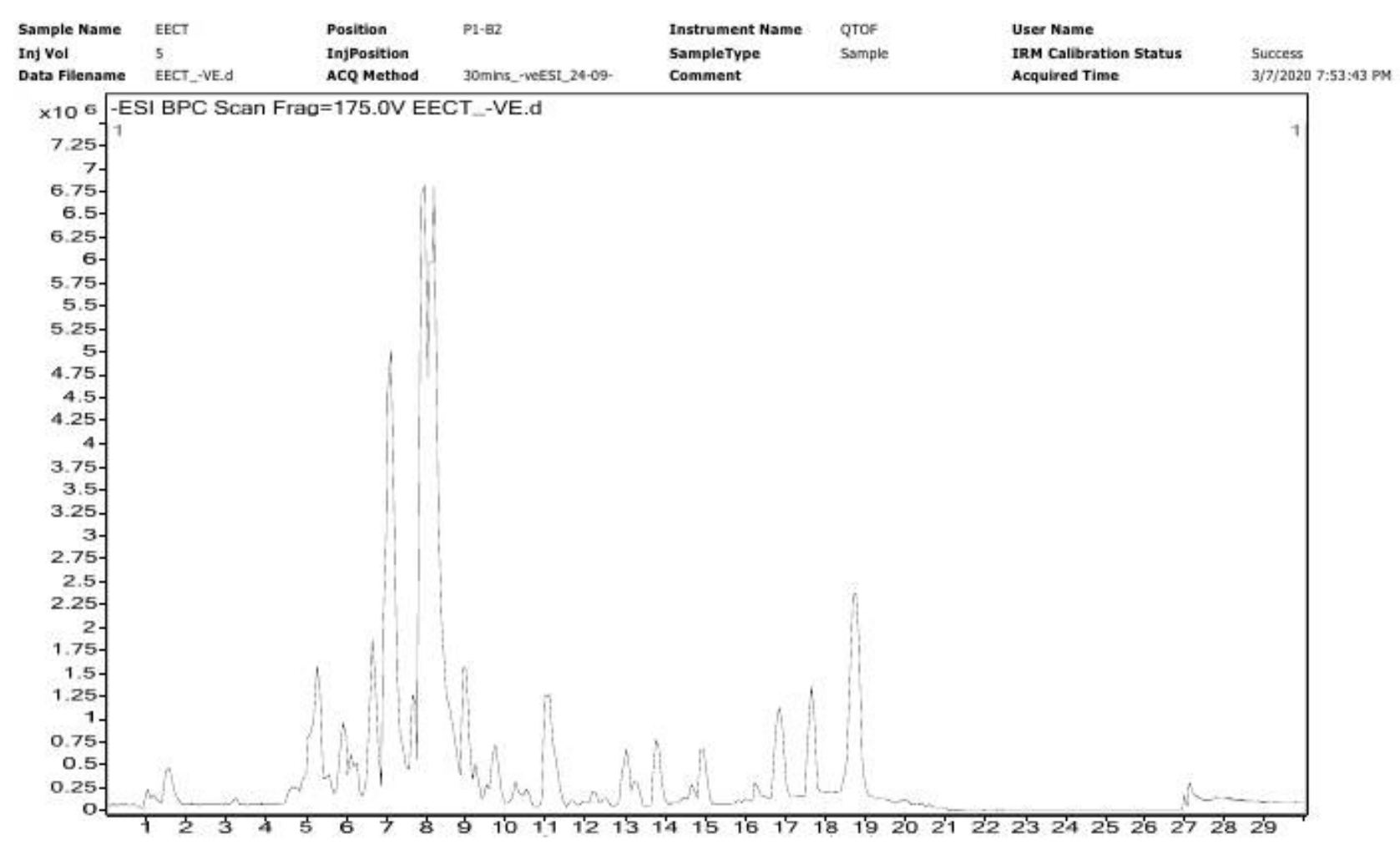

Fig. 2. HR-LCMS chromatogram (Negative ESI) of ethanolic root extract of Clitoria ternatea L.

Table 2. HR-LCMS analysis of ethanolic root extract of Clitoria ternatea L. at Positive ESI

\begin{tabular}{|c|c|c|c|c|c|c|}
\hline Sl. No. & Compound & $\begin{array}{l}\text { Retention } \\
\text { time }\end{array}$ & Mass & $\begin{array}{l}\text { Molecular } \\
\text { formula }\end{array}$ & $\begin{array}{l}\text { DB diff } \\
(\mathrm{ppm})\end{array}$ & $\begin{array}{l}\text { Hits } \\
\text { (DB) }\end{array}$ \\
\hline 1 & Chelidonine (+) & 1.245 & 353.1258 & C20 H19 N O5 & 1.49 & 63 \\
\hline 2 & Retusin dimethyl ether & 1.586 & 312.0993 & C18 H16 O5 & 1.46 & 27 \\
\hline 3 & Elephantopin & 1.638 & 360.1199 & C19 H20 O7 & 2.83 & 31 \\
\hline 4 & Sebacic acid & 1.874 & 202.1222 & $\mathrm{C} 10 \mathrm{H} 18 \mathrm{O} 4$ & -8.33 & 2 \\
\hline 5 & Mycophenolic acid & 1.986 & 320.1271 & C17 H20 O6 & -3.53 & 31 \\
\hline 6 & Deoxysappanone B 7,3'-dimethyl ether acetate & 6.05 & 356.1247 & $\mathrm{C} 20 \mathrm{H} 20 \mathrm{O} 6$ & 3.57 & 21 \\
\hline 7 & $\begin{array}{l}\text { 7-[2 trifluoromethyl-4-(2-hydroxyphenyl) -1,3-dioxan- } \\
\text { cis-5-yl]-hept-5Z-enoic acid }\end{array}$ & 6.439 & 374.1351 & C18 H21 F3 O5 & -2.75 & 21 \\
\hline 8 & Deoxysappanone B 7,3'-Dimethyl ether acetate & 6.713 & 356.124 & $\mathrm{C} 20 \mathrm{H} 20 \mathrm{O} 6$ & 3.43 & 21 \\
\hline 9 & 3-hydroxy-3',4'-dimethoxyflavone & 8.097 & 298.0831 & C17 H14 O5 & 3.5 & 16 \\
\hline 10 & Isotectorigenin, 7-Methyl ether & 8.231 & 328.094 & C18 H16 O6 & 1.79 & 7 \\
\hline 11 & Tuberonic acid & 9.675 & 226.1201 & C12 H18 O4 & 1.69 & 20 \\
\hline 12 & Gibberellin A29 & 10.232 & 348.1583 & C19 H24 O6 & -3.03 & 29 \\
\hline 13 & Anisodamine & 10.492 & 305.1619 & C17 H23 NO4 & 2.59 & 27 \\
\hline 14 & 8-(1-Hydroxyethyl)etodolac & 10.621 & 303.1467 & C17 H21 NO4 & 1.3 & 47 \\
\hline 15 & Triptonide & 11.506 & 358.1407 & $\mathrm{C} 20 \mathrm{H} 22 \mathrm{O} 6$ & 2.55 & 36 \\
\hline 16 & Naloxol & 12.009 & 329.1622 & C19 H23 NO4 & 1.5 & 49 \\
\hline 17 & Butorphanol & 12.846 & 219.2221 & C12 H29 NO2 & -10.41 & 1 \\
\hline 18 & 2-Isoprenyl-3-hydroxy-5-methyl-a-pyrone & 13.091 & 194.0939 & C11 H14 O3 & 2.06 & 13 \\
\hline 19 & Lys Ser Lys & 14.17 & 361.224 & C15 H31 N5O5 & 23.0 & 3 \\
\hline 20 & LTB4 ethanol amide & 15.637 & 379.2733 & C22 H37 NO4 & -2.86 & 7 \\
\hline 21 & Cer(d18:0/16:0) & 17.631 & 539.5262 & C34 H69 NO3 & 2.87 & 1 \\
\hline 22 & Anandamide $(20: 2, \mathrm{n}-6)$ & 18.23 & 351.3129 & C22 H41 NO2 & 2.45 & 1 \\
\hline 23 & (Z)-N-(2-hydroxyethyl)icos-11-Enamide & 19.369 & 353.3286 & C22 H43 NO2 & 2.33 & 1 \\
\hline 24 & Docosanamide & 19.372 & 339.351 & $\mathrm{C} 22 \mathrm{H} 45 \mathrm{NO}$ & -4.3 & 1 \\
\hline
\end{tabular}


Table 3. HR-LCMS analysis of ethanolic root extract of Clitoria ternatea L. at Negative ESI

\begin{tabular}{rlrrrrr}
\hline Sl. No. & \multicolumn{1}{c}{ Compound } & Retention time & Mass & Molecular formula & $\begin{array}{c}\text { DB diff } \\
\text { (ppm) }\end{array}$ & $\begin{array}{l}\text { Hits } \\
\text { (DB) }\end{array}$ \\
\hline 1 & Pectolinarin & 4.894 & 622.187 & C29H34 O15 & 3.6 & 2 \\
\hline 2 & Glycogen & 5.282 & 666.216 & C24H42 O21 & 8.78 & 3 \\
\hline 3 & 5-Formiminotetrahydrofolic Acid & 5.95 & 472.181 & C20H24N8 O6 & -0.06 & 14 \\
\hline 4 & Levan & 6.54 & 504.16 & C18 H32 O16 & 11.9 & 9 \\
\hline 5 & Maltotriose & 6.54 & 504.163 & C18 H32 O16 & 11.81 & 6 \\
\hline 6 & Tyr Gln Glu & 6.622 & 438.1768 & C19H26N4 O8 & -3.98 & 16 \\
\hline 7 & Sappanone A 7-methyl Ether & 6.97 & 298.0845 & C17 H14 O5 & -1.3 & 7 \\
\hline 8 & Isotectorigenin, 7-Methyl ether & 6.982 & 328.095 & C18 H16 O6 & -2.6 & 2 \\
\hline 9 & 6,4'-Dimethoxyflavon & 7.05 & 282.0894 & C17 H14 O4 & -0.76 & 16 \\
\hline 10 & Mucronulatol(++-)) & 7.151 & 302.116 & C17 H18 O5 & -2.14 & 12 \\
\hline 11 & Elephantopin & 7.894 & 360.1233 & C19 H20 O7 & -6.66 & 33 \\
\hline 12 & Epiafzelechin trimethyl Ether & 7.962 & 316.132 & C18 H20 O5 & -4.6 & 13 \\
\hline 13 & Neu5Acalpha2-6Galbeta1-4Glcbeta-Sp & 7.96 & 702.233 & C25H42N4O19 & 14.96 & 5 \\
\hline 14 & Biochanin A, dimethyl Ether & 8.202 & 312.10 & C18 H16 05 & -7.2 & 7 \\
\hline 15 & 25-O-Deacetylrifabutin N-oxide & 9.7 & 820.4247 & C44H60N4O11 & 1.43 & 2 \\
\hline 16 & Telmisartan & 10.997 & 514.2466 & C33H30N4O2 & -18.91 & 4 \\
\hline 17 & Cys Tyr Arg & 14.815 & 440.185 & C18H28N6O5S & -3.54 & 48 \\
\hline 18 & DL-8-hydroxy stearic acid & 18.598 & 300.2679 & C18 H36 O3 & -4.69 & 53 \\
\hline
\end{tabular}
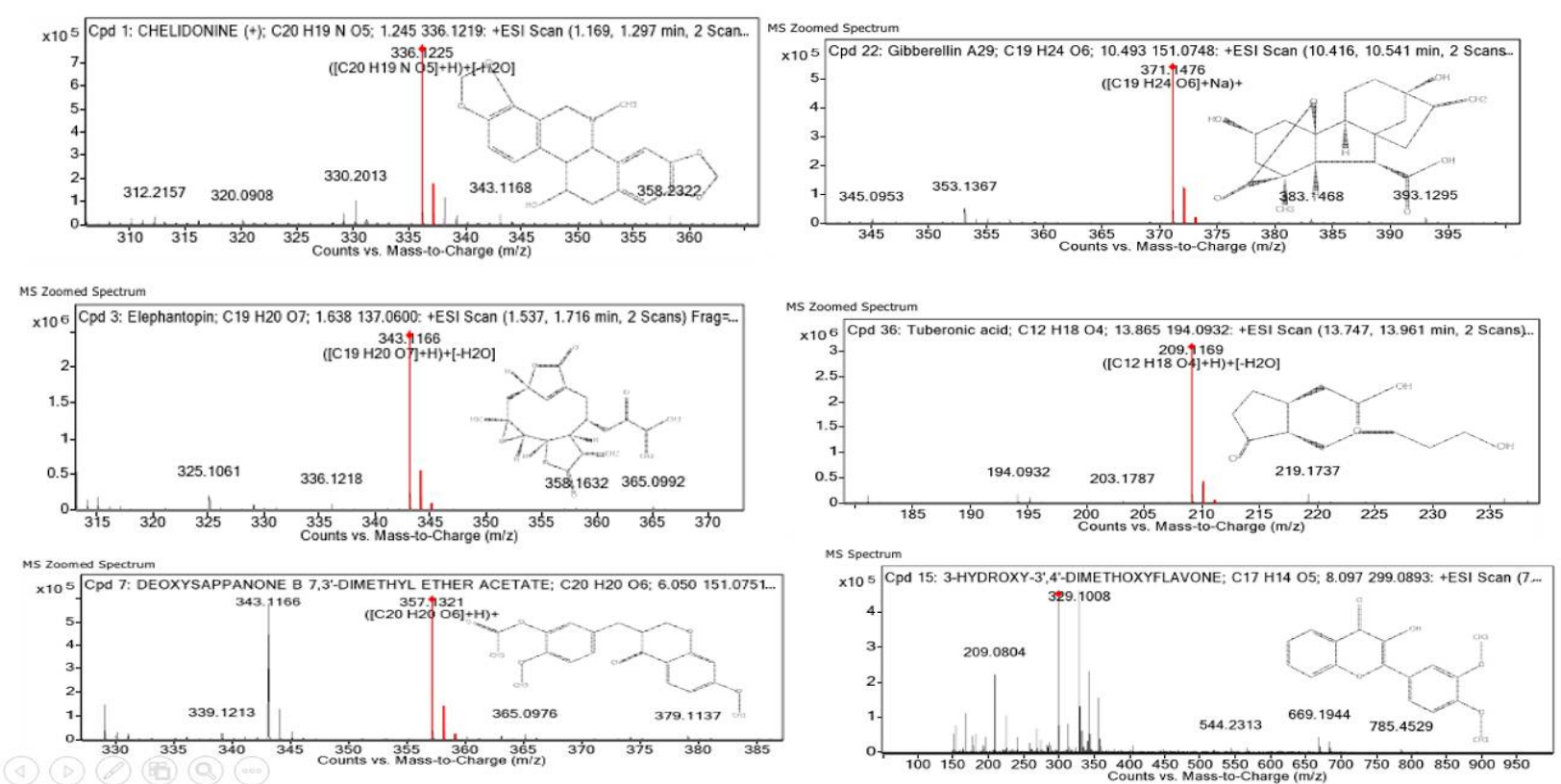

Fig. 3. HR-LCMS- MS Zoomed Spectrum of different compounds detected from ethanolic root extract of Clitoria ternatea L. at Positive ESI.
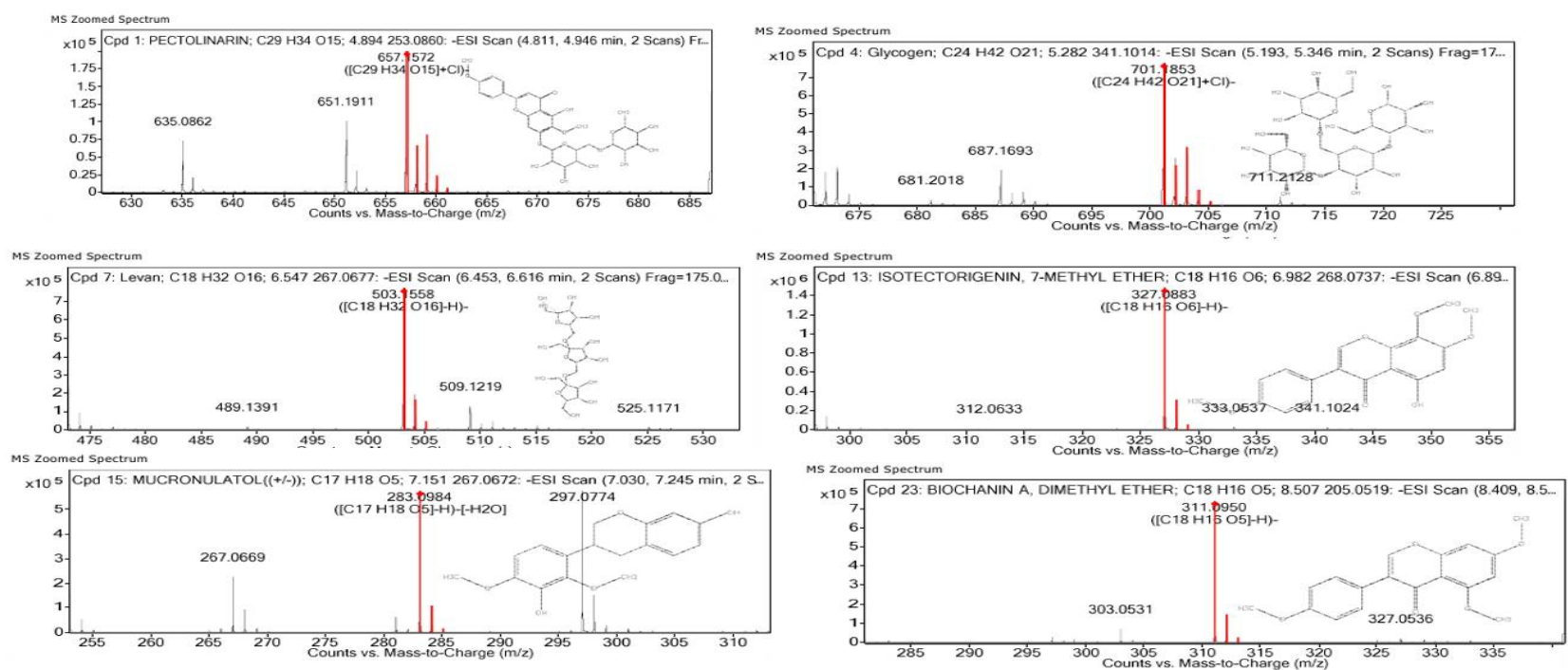

Fig. 4. HR-LCMS- MS Zoomed Spectrum of different compounds detected from ethanolic root extract of Clitoria ternatea L. at Negative ESI. 
various secondary active metabolites from this traditionally well-known medicinal plant.

\section{Acknowledgements}

The authors are grateful to the SAIF lab authorities (IIT -Bombay) and the Management of the C.L.Baid Metha College of Pharmacy for providing the required facilities to carry out this research work. This publication is a part of the Ph.D. Thesis (candidate name - JIJI K N) of The Tamil Nadu DR.M.G. R Medical University, Chennai, Tamil Nadu, India.

\section{Authors' contributions}

PM guided JKN in planning, designing and conducting the research experiment to obtain the data. PM and JKN participated in the manuscript draft and have thoroughly checked and revised the manuscript. The author(s) read and approved the final manuscript.

\section{Conflict of interests}

The authors declared that they have no conflict of interest.

\section{References}

1. Gratus C, Damery S, Wilson S, Warmington S, Routledge P, Grieve $\mathrm{R}$, Steven N, Jones J, Greenfield S. The use of herbal medicines by people with cancer in the UK: a systematic review of the literature. Q J Med.2009;102:831-42. https://doi.org/10.1093/qjmed/hcp137

2. Taylor S, Berridge V. Medicinal plants and malaria: an historical case study of research at the London School of Hygiene and Tropical Medicine in the twentieth century. Trans R Soc Trop Med Hyg. https://doi.org/10.1016/j.trstmh.2005.11.017 2006;100(8):707-14.

3. Vickers A, Zollman C. ABC of complementary medicine herbal medicine. BMJ. http://doi.org/10.1136/bmj.319.7216.1050 1999;319:1050-53.

4. Fikrat IA. Cancer chemopreventive and tumoricidal properties of Saffron (Crocus sativus L.). Exp Biol Med. 2002;227:20-25. https://doi.org/10.1177/153537020222700104

5. Singh RH, Narsimhamurthy K, Singh G. Neuronutrient impact of Ayurvedic Rasayana therapy in brain ageing. Biogerontology. 2008; 9:369-74. https://doi.org/10.1007/s10522-008-9185-z

6. Jiji KN. Muralidharan P. Neuropharmacological Potential of Clitoria ternatea Linn. - A Review. Research J Pharm and Tech. 2020;13(11):1-6. https://doi.org/10.5958/0974-360X.2020.00960.9

7. Manjula $\mathrm{P}$, Mohan $\mathrm{CH}$, Sreekanth D. Phytochemical analysis of Clitoria ternatea (Linn.): A valuable medicinal plant. Journal of Indian Botanical Society. 2013; 92:(3\&4):173-78.

8. Mukherjee PK, Kumar V, Mal M, Houghton PJ. Acetyl cholinesterase inhibitors from plants. Phytomedicine. 2007; 14:289-300. https://doi.org/10.1016/j.phymed.2007.02.002

9. Jain NN, Ohal CC, Shroff SK, Bhutada RH, Somani RS, Kasture VS. Clitorea ternatea and the CNS. Pharmacol Biochem Behav. 2003; 75:529-36.
10. Parimaladevi B, Boominathan R, Mandal SC. Evaluation of antipyretic potential of Clitorea ternatea L. extract in rats. Phytomedicine. 2004;11:323-26. https://doi.org/10.1016/s0367326x(03)00057-1

11. Kulkarni C, Pattanshetty JR, Amruthraj G. Effect of alcoholic extract of Clitorea ternatea Linn. on central nervous system in rodents. Indian J Exp Biol. 1988; 26:957-60. PMID: 3254867

12. Nadkarni KM. Indian Materia Medica. 3rd ed. Bombay: Popular Publication;1976. p.20-45.

13. Daisy P, Rajathi M. Hypoglycemic effects of Clitorea ternatea Linn. (Fabaceae) in alloxan induced diabetes in rats. Trop J Pharm Res. 2009;8:393-98.

14. Yadav RNS, Agarwal M. Phytochemical analysis of some medicinal plants. Journal of Phytology. 2011;3(12):10-14.

15. Pulok K Mukherjee. Quality Control and Evaluation of Herbal Drugs - Evaluating Natural Products and Traditional Medicine. Elsevier; 2019. p.79-149

16. Digambar SP, Jyoti G, Sahera N. Antimicrobial activity and HRLCMS analysis of methanolic extract of Calotropis gigantea. International Journal of Advanced Science and Research. 2019;4(1):19-24.

17. Patil AP, Patil RV. Clitoria ternatea Linn.: An overview. IJPSR 2011;3:20-23.

18. Rai KS. Neurogenic potential of Clitoria ternatea aqueous roo extract-a basis for enhancing learning and memory. Int J Pharm Sci Rev Res. 2010;4:186-91. https://doi.org/10.5281/zenodo.1074966

19. Taranalli AD, Cheeramkuzhy TC. Influence of Clitoria ternatea extracts on memory and central cholinergic activity in rats. Pharm Biol. 2000;38(1):51-56. https://doi.org/10.1076/13880209(200001)3811-BFT051

20. Rai KS, Murthy KD, Karanth KS, Nalini K, Rao MS. Clitoria ternatea root extract enhances acetylcholine content in rat hippocampus Fitoterapia. 2002;73:685-89. https://doi.org/10.1016/S0367326X(02)00249-6

21. Margret AA, Begum TN, Parthasarathy S, Suvaithenamudhan S. A strategy to employ Clitoria ternatea as a prospective brain drug confronting monoamine oxidase (MAO) against neurodegenerative diseases and depression. Nat prod Bioprospect. 2015;5:293-306. https://doi.org/10.1007/s13659-0150079-x

22. Parvathi M, Ravishankar K. Evaluation of antidepressant, motor coordination and locomotor activities of ethanolic root extract of Clitoria ternatea. J Nat Remedies. 2013;13:19-24. https://doi.org/ 10.18311/jnr/2013/113

\section{Additional information}

Peer review information: Plant Science Today thanks Sectional Editor and the other anonymous reviewers for their contribution to the peer review of this work.

Reprints and permissions information is available at https://horizonepublishing.com/journals/index.php/PST/open_access_policy

Publisher's Note: Horizon e-Publishing Group remains neutral with regard to jurisdictional claims in published maps and institutional affiliations.

To cite this article: Jiji K N, Muralidharan P. Identification and characterization of phytoconstituents of ethanolic root extract of Clitoria ternatea L. utilizing HR-LCMS analysis. Plant Science Today. 2021;8(3):535540. https://doi.org/10.14719/pst.2021.8.3.1141

Plant Science Today, published by Horizon e-Publishing Group, is covered by Scopus, Web of Science, BIOSIS Previews, Clarivate Analytics, etc. See https://horizonepublishing.com/journals/index.php/PST/indexing_abstracting 